\title{
Glyceryl Ether (mono-tert-butoxypropanediol) in Emulsion System
}

(Eter Gliseril (mono-tert-butoksipropanadiol) dalam Sistem Emulsi)

\author{
YUSRABBIL AMIYATI YUSOF*, AZHAR ARIFFIN \& ZAFARIZAL ALDRIN AZIZUL HASAN
}

\begin{abstract}
This paper reports the effects of glyceryl ether specifically mono-tert-butoxypropanediol on oil in water emulsion system. Based on 12 HLB value, screening for stable emulsions was carried out without the presence of glyceryl ether. A stable emulsion was used as a control. Then the effects of glyceryl ether on the emulsion system were investigated. The emulsions prepared were analyzed for stability, viscosity, $\mathrm{pH}$ value, particle size, in vitro dermal irritation potential, in vitro ocular irritation potential and also moisturizing property. The incorporation of glycerol in the emulsion system was also done for comparison. Emulsions with glyceryl ether showed lower viscosity values than emulsions with glycerol. Furthermore, the emulsions also exhibited moisturizing property compared to the control emulsion. Glyceryl ether is suitable to be used in cosmetic products which require reduced viscosity but retain its skin hydration property.
\end{abstract}

Keywords: Diol; emulsion; glyceryl ether

\section{ABSTRAK}

Kertas ini melaporkan kesan eter gliserol khususnya mono-tert-butoksipropanadiol terhadap sistem emulsi minyak dalam air. Berdasarkan nilai HLB 12, saringan untuk mendapatkan emulsi yang stabil telah dijalankan tanpa kehadiran eter gliserol. Emulsi yang stabil tersebut telah digunakan sebagai kawalan. Kemudian kesan eter gliserol pada sistem emulsi telah dikaji. Emulsi tersebut dianalisis untuk kestabilan, kelikatan, nilai pH, saiz zarah, potensi kerengsaan kulit in vitro, potensi kerengsaan okular in vitro dan sifat pelembapan. Penggunaan gliserol dalam sistem emulsi juga telah dilakukan untuk perbandingan. Emulsi yang mengandungi eter gliserol mempunyai nilai kelikatan yang lebih rendah daripada emulsi yang mengandungi gliserol. Emulsi tersebut juga mempamerkan sifat pelembapan berbanding kawalan. Eter gliserol sesuai untuk digunakan dalam produk kosmetik yang memerlukan kelikatan yang rendah tetapi masih mengekalkan ciri penghidratan kulit.

Kata kunci: Diol; emulsi; eter gliserol

\section{INTRODUCTION}

Today, the majority of commercially available glycerol results from the purification of the co-product obtained from oleochemical industry (Ayoub \& Abdullah 2012; Patel et al. 2006). Being one of the basic oleochemicals, glycerol plays an important role in influencing the market of oleochemical industries worldwide. According to ABG Inc. Company as cited in Ayoub and Abdullah, it is estimated that the production of glycerol would reach 5.8 billion pounds in 2020. This is due to the demand of biodiesel that is projected at 8 billion gallons in 2020 (Ayoub \& Abdullah 2012). This is a good sign for oleochemical industry in order to replace a petroleum-based product in possible applications where the oleochemical-based product is claimed to be more environmentally friendly and it is a renewable resources compared to petroleum-based product.

Glycerol is a clear, water-white, sweet, viscous, odourless, colourless and hygroscopic liquid at ordinary room temperature above its melting point (Heming 1999; Knothe et al. 2005). It is stable under most conditions, non-toxic, easily digested and environmentally safe (Jungermann \& Sonntag 1991).
Glycerol is used as an agent in cosmetics, shampoos, soaps, herbal remedies, pharmaceuticals and other household products (Heming 1999). It is versatile and is used in more than 1000 different products due to its nontoxic properties for use in foods, as stated by SDAScience. org (Peterman 2011). Besides being used directly in consumer product formulations, glycerol has been used as a starting material to produce other intermediate compounds or products with other possible applications. This will add value to glycerol by varying its applications.

Glyceryl ether is one of the glycerol derivatives and potentially used in many fields. The use of glyceryl ether in microemulsion system has been investigated since 1993 (Fukuda et al. 1993). Blute et al. (1998) reported that the incorporation of glyceryl ether formed a better microemulsion system. Recently, it was found that the glyceryl ether could be used as a potential alternative co-surfactant for preparing microemulsion such as agrochemical products for crop care and public health sectors (Ismail et al. 2014). Nevertheless, this study focused on its application in macroemulsions. Emulsions are defined as disperse systems in which two or sometimes 
several almost insoluble liquid phases are firmly mixed. There is either oil in water $(\mathrm{o} / \mathrm{w})$ or water in oil (w/o) emulsion in the simplest case. Multiphase emulsions are also quite common such as water in oil emulsion that can be dispersed in water to obtain w/o/w emulsion for cosmetic and other technical applications (Rieger \& Rhein 1997). In this study, the effects of glyceryl ether on macroemulsions specifically for cosmetic application were investigated.

\section{MATERIALS}

Steareth-2 and Steareth-21 were purchased from Uniqema. Glyceryl ether (major component being mono-tertbutoxypropanediol $>85 \%$ ) was synthesized according to Yusof et al. (2010), by reacting glycerol and tert-butanol in the presence of an acidic catalyst. Medium chain triglyceride (MCT) was purchased from Intermed Sdn Bhd. All other reagents were of analytical grades and used as received unless stated otherwise.

\section{METHODS}

Potential applications of glyceryl ether (mono-tertbutoxypropanediol) in emulsion systems were explored. Based on hydrophilic-lipophilic balance (HLB), emulsion systems for oil in water were developed. The concept of using the HLB value for the formation of the emulsion was applied according to Rieger and Rhein (1997). Based on 12 HLB value, screening for stable emulsions was carried out without the presence of glyceryl ether or glycerol by varying the amount of surfactant mixture. Glycerol or glyceryl ether was only incorporated when a stable emulsion was obtained. The stable emulsion in the absence of glyceryl ether or glycerol, so-called placebo was used as a control in this study.

\section{PREPARATION OF MACROEMULSIONS}

Melted lipid phase consisting of 5\% MCT and $1.65 \%$ lipophilic surfactant (Steareth 2) was added to a hot aqueous solution containing $3.35 \%$ hydrophilic surfactant (Steareth-21) and 1-5\% glyceryl ether or glycerol. Both phases (lipid and water phases) were heated to $70^{\circ} \mathrm{C}$. The mixture was homogenized at $10,000 \mathrm{rpm}$ for $2 \mathrm{~min}$ using Polytron PT 3100 homogenizer (Kinematica Inc, Switzerland). Finally, the emulsion formed was stirred until ambient temperature $\left(25^{\circ} \mathrm{C}\right)$ was reached.

\section{STABILITY STUDY OF EMULSIONS}

In order to identify the stable emulsion, two methods for stability test were conducted. The first method was the observation in phase separation of emulsions at different temperatures. The observation was recorded periodically. Each sample was divided into three sample bottles and stored at three different conditions, namely: room temperature; freeze/thaw (6 days) - sample was stored for $24 \mathrm{~h}$ at room temperature and then stored at $5^{\circ} \mathrm{C}$ for $24 \mathrm{~h}$. The cycle was repeated for 3 cycles; and $45^{\circ} \mathrm{C}$ ( 3 months). The second method was the accelerated test using a LUMiFuge stability analyzer. The method which is using near infrared transmission measurements during centrifugation was applied in stability study by other researchers (Kanagaratnam et al. 2013; Kuentz \& Röthlisberger 2003). The samples were filled into rectangular polycarbonate cells with a stopper and then placed horizontally in the centrifuge. This system measures near infrared (NIR) transmission profiles continuously during centrifugation resulting in 256 measurements. LUMiFuge software calculated the integral of every transmission curve over a chosen length (the sample length). A graphical representation of transmission as a function of position presents the transmission profile (Kanagaratnam et al. 2013). From the data obtained, the software also calculates the instability index of the samples.

\section{PARTICLE SIZE ANALYSIS}

Particle size analysis was carried out by a laser diffraction particle analyser, the Malvern Hydro 2000S (Worcestershire, England). The particle size of the emulsions was described by the cumulants mean diameter according to StanleyWood and Lines (1992) as cited in Loo et al. (2014).

\section{VISCOSITY}

A rheometer, MCR 300, PAAR PHYSICA was used to determine the viscosity of prepared emulsions at $25^{\circ} \mathrm{C}$.

\section{IN VITRO DERMAL AND OCULAR IRRITECTION ASSAYS}

The dermal and ocular irritection assays are quantitative in vitro test methods that mimic acute dermal and ocular irritation tests. To perform the ocular irritection standardized assay, the test sample is applied to a synthetic biobarrier composed of a semi-permeable membrane. While for dermal irritection standardized assay, the test sample is applied to a similar synthetic biobarrier that is coated with a dye-containing keratin-collagen matrix. Following application, the sample is absorbed and permeates through this synthetic biobarrier to gradually come into contact with a proprietary solution containing highly ordered globulins and glycoproteins. Reaction of the test sample with these proteins and macromolecular complexes promotes conformational changes that may be readily detected as an increase in the turbidity of the protein solution. With the dermal irritection test, turbidity as well as the dye that has been dissociated from the biobarrier during transit of the applied sample was detected spectrophotometrically at a wavelength of $450 \mathrm{~nm}$. With the ocular irritection test, turbidity was detected spectrophotometrically at a wavelength of $405 \mathrm{~nm}$. Comparison of the optical density to those produced by standard chemical irritants permits calculation of an irritancy score that has been shown to be directly related to the potential corneal or dermal irritancy of the test material. 
The dermal irritancy potential of a test sample is expressed as a Human Irritancy Equivalent (HIE), whereas the ocular irritancy potential of a test sample is expressed as an Irritection Draize Equivalent (IDE). IDE and HIE have been reported to correlate well with in vivo investigations by the Draize method and human test, respectively (Ismail et al. 2013; Zafarizal Aldrin et al. 2005).

\section{ACUTE MOISTURIZING TEST}

A study on acute moisturizing effect of prepared emulsions was conducted on 20 subjects. For the study, the skin hydration was measured before and after product application. The product was applied on pre-marked test areas of the forearms while the control was untreated skin. The measurement was taken before and at 30, 60, 90, 120 and $180 \mathrm{~min}$ after product application. All measurements were carried out using the Corneometer CM 825 (Courage and Khazaka, Germany), which measures the skin moisture. The measuring principle of the instrument is based on the capacitance measurement of a dielectric medium. The dielectric constant of the skin changes with the water content. The changes in water content of the stratum corneum are converted to arbitrary units of hydration (Berardesca et al. 1997).

\section{RESULTS AND DISCUSSION}

Although phase separation of some emulsions did not occur when observed at ambient temperature, the LUMiFuge stability analyzer was able to show undesirable instability index. From both stability test methods, it was found that LUMiFuge stability analyzer is very useful in rapid determination of emulsion stability. A stable emulsion was then used for further study by incorporating glyceryl ether in the emulsion system. Glycerol was incorporated in the emulsion system as a benchmark. The emulsions were analyzed for stability, viscosity, $\mathrm{pH}$ value, particle size, in vitro dermal irritation potential, in vitro ocular irritation potential and also moisturizing property. The results from the accelerated test indicated that all emulsions are considered stable at $25^{\circ} \mathrm{C}$ for six months and at $45^{\circ} \mathrm{C}$ for three months based on a very low instability index (Table 1). The higher the value of the instability index, the more unstable the emulsion is within the estimated period of time. The highest value of the instability index is 1 .

The viscosity of the emulsions were measured and the results showed that the viscosity of the emulsions increased with increasing amount of glycerol and decreased with increasing amount of glyceryl ether as shown in Figure 1. According to Aghel et al. (2007), glycerin was used as viscosity modifier in the formulation of a clear liquid shampoo base.

TABLE 1 . The instability index of emulsions at $25^{\circ} \mathrm{C}$ for 6 months and at $45^{\circ} \mathrm{C}$ for 3 months based on the LUMiFuge Stability Analyzer

\begin{tabular}{lcc}
\hline \multirow{2}{*}{ Sample } & \multicolumn{2}{c}{ Instability index } \\
\cline { 2 - 3 } & $25^{\circ} \mathrm{C}$ for 6 months & $45^{\circ} \mathrm{C}$ for 3 months \\
\hline Placebo (Control) & $<0.01$ & $<0.01$ \\
Emulsion containing 1\% glycerol & $<0.01$ & $<0.01$ \\
Emulsion containing 5\% glycerol & $<0.01$ & $<0.01$ \\
Emulsion containing 1\% glyceryl ether & $<0.01$ & $<0.01$ \\
Emulsion containing 5\% glyceryl ether & $<0.01$ & $<0.01$ \\
\hline
\end{tabular}

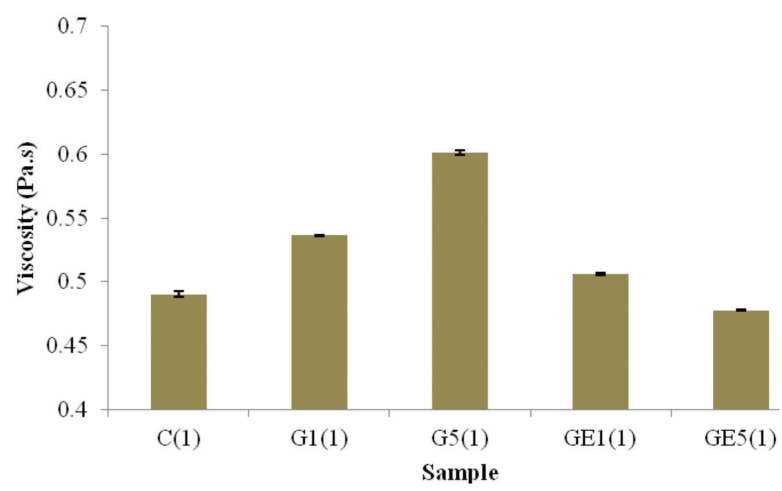

FIGURE 1 . The viscosity of the prepared emulsions

wherein $\mathrm{C}(1)=$ Placebo

G1 $(1)=$ Emulsion containing $1 \%$ glycerol

G5(1) $=$ Emulsion containing $5 \%$ glycerol

GE1 $(1)=$ Emulsion containing $1 \%$ glyceryl ether

GE5 $(1)=$ Emulsion containing $5 \%$ glyceryl ether 
The $\mathrm{pH}$ values of the emulsions produced were in the range of 6 to 6.5 . The near neutral $\mathrm{pH}$ value correlates with low skin irritation (Baranda et al. 2002). The particle size of the emulsions produced (5 2-7.7 $\mu \mathrm{m})$ remained unchanged even after two years of storage at ambient temperature. Thus, the emulsions produced were stable upon storage.

A cosmetic product should not induce any irritation to the skin. Furthermore, it is preferable to have a product which also does not irritate the eyes. The irritation potential of a compound to the skin and eye can be assessed and predicted by using in vitro dermal and ocular irritection assays, respectively (Ismail et al. 2013; Zafarizal Aldrin et al. 2005). The dermal or ocular irritection assay is an alternative method to animal irritancy studies (Draize Test) that mimic biochemical phenomena. The in vitro irritection assays have been reported to correlate with in vivo irritancy tests (Sina et al. 1995).

The in vitro dermal irritection assay (Figure 2) shows that all emulsions are classified as non-irritant to the skin based on the HIE score (below 0.9). Meanwhile the in vitro ocular irritection assay shows that all emulsions produced are classified as minimal or minimal $/ \mathrm{mild}$ to the skin (Figure 3 ). Therefore, the emulsions produced could be used either for skin or face products.

Besides measuring the viscosity, $\mathrm{pH}$ value, particle size, in vitro dermal and ocular irritection of the emulsions,

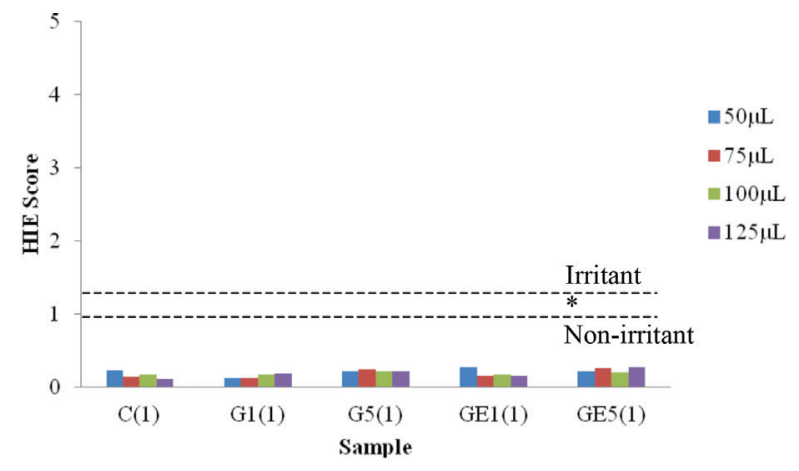

* Non-Irritant/Irritant

FIGURE 2. Results of in vitro dermal irritection assay of the prepared emulsions

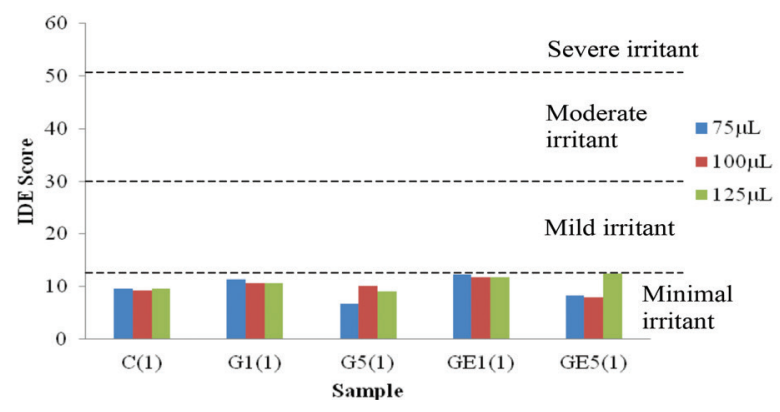

FIGURE 3 . Results of in vitro ocular irritection assay of the prepared emulsions the effects of glyceryl ether in emulsion on skin hydration were also conducted. The tests were carried out on 20 test subjects and the readings of skin hydration, untreated and treated with the emulsions were recorded every half an hour for $3 \mathrm{~h}$. Figure 4 shows the percentage variation in hydration of the emulsions tested. There was no variation of skin hydration on untreated areas (UT) indicating that the test was well controlled.

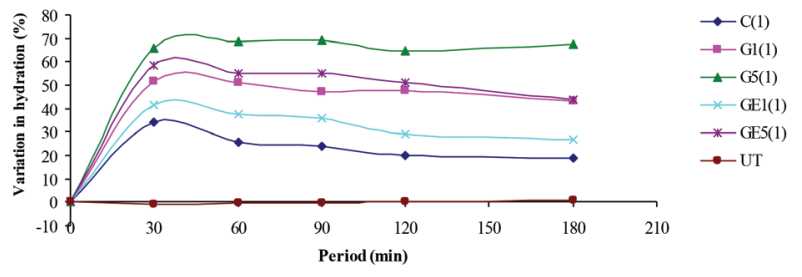

FIGURE 4. Results of moisturizing tests of the prepared emulsions

wherein $\mathrm{C}(1)=$ Placebo

G1(1) = Emulsion containing $1 \%$ glycerol G5(1) = Emulsion containing 5\% glycerol GE1(1) = Emulsion containing $1 \%$ glyceryl ether GE5(1) = Emulsion containing $5 \%$ glyceryl ether $\mathrm{UT}=$ Untreated

Glycerol is a well known humectant. Humectant attracts water and help to keep that water bound in stratum corneum (Dobos 2014). The presence of 1\% and $5 \%$ glycerol in the emulsion significantly increased the skin hydration compared to placebo $(p<0.05)$. The presence of $1 \%$ and $5 \%$ glyceryl ether in the emulsions also significantly increased the percentage variation in hydration compared to placebo $(p<0.05)$. Even though the moisturizing property of glyceryl ether is lower than glycerol, it still exhibits a good moisturizing effect to skin. A high skin hydration level of emulsion containing glycerol was reported by Alber et al. (2014). The superior moisturizing property of glycerol could be attributed to the three hydroxyl groups in the glycerol molecule, whereas the glyceryl ether has only two hydroxyl groups. The presence of more hydroxyl group could bind more water, thus increase skin hydration.

\section{CONCLUSION}

The utilization of glyceryl ether (mono-tertbutoxypropanediol) in macroemulsions was successfully investigated. Emulsions with glyceryl ether showed lower viscosity values than emulsions with glycerol. The product also exhibited good moisturizing property even though it is not as superior as glycerol. Glyceryl ether could be an alternative for glycerol when one wants to formulate a product with lower viscosity yet moisturize the skin.

\section{ACKNOWLEDGEMENTS}

The authors would like to thank the Malaysian Palm Oil Board (MPOB), Malaysia for the financial support. 


\section{REFERENCES}

Aghel, N., Moghimipour, E. \& Raies, A. 2007. Formulation of a herbal shampoo using total saponins of Acanthophyllum Squarrosum. Iranian Journal of Pharmaceutical Research 6(3): 167-172.

Alber, C., Buraczewska-Norin, I., Kocherbitov, V., Saleem, S., Lodén, M. \& Engblom, J. 2014. Effects of water activity and low molecular weight humectants on skin permeability and hydration dynamics - a double-blind, randomized and controlled study. International Journal of Cosmetic Science 36: 412-418.

Ayoub, M. \& Abdullah,A.Z. 2012. Critical review on the current scenario and significance of crude glycerol resulting from biodiesel industry towards more sustainable renewable energy industry. Renewable and Sustainable Energy Reviews 16: 2671-2686.

Baranda, L., Gonzalez-Amaro, R., Torress-Alvarez, B., Alvarez, C. \& Ramirez, V. 2002. Correlation between pH and irritant effect of cleansers marketed for dry skin. International Journal of Dermatology 41: 494-499.

Berardesca, L., Masson, P., Rodrigues, L., Gummer, C.L., Lévéque, Loden, M., Piérard, G., Rogiers, V., Salter, D., Sauermann, G., Serup, J. \& Trevethan, M.A. 1997. EEMCO guidance for the assessment of stratum corneum hydration: Electrical methods. Skin Research and Technology 3: 126132.

Blute, I., Kronberg, B., Svensson, M. \& Unelius, R. 1998. Phase-behaviour of alkyl glycerol ether surfactants. Tenside Surfactant Detergent 35(3): 207-212.

Dobos, K. 2014. How do Skin Moisturizers Work? http:// chemistscorner.com/how-do-skin-moisturizers-work/. Accessed on 18 December 2014.

Fukuda, K., Soderman, O., Lindman, B. \& Shinoda, K. 1993. Microemulsions formed by alkyl polyglycosides and an alkyl glycerol ether. Langmuir 9(11): 2921-2925.

Heming, M. 1999. The World Glycerine Market. CTVONetworkshop. HB International. http://www.dainet.de/fnr/ ctvo/byproducts/heminghbi.doc. Accessed on 2 January 2008.

Ismail, A.R., Wan Nurul Fatihah, W.Y., Rusli, D. \& Hazimah, A.H. 2014. Effect of glycerol derived co-surfactant on the ternary phase behaviour of palm-based microemulsions. Journal of Oil Palm Research 26(3): 240-250.

Ismail, R., Yusof, N.Z., Aldrin, Z. \& Hassan, H.A. 2013. Safety assessment of oil palm phenolics as active ingredient for topical application. Journal of Oil Palm Research 25(2): 188-196.

Jungermann, E. \& Sonntag, N.O.V. 1991. Cosmetic Science and Technology Series. Vol 11. Glycerine: A Key Cosmetic Ingredient. New York: Marcel Decker, Inc.

Kanagaratnam, S., Hoque, M.E., Sahri, M.M. \& Spowage, A. 2013. Investigating the effect of deforming temperature on the oil-binding capacity of palm oil based shortening. Journal of Food Engineering 118: 90-99.

Knothe, G., Gerpen, J.V. \& KrahL, J. 2005. The Biodiesel Handbook. Urbana, Illinois: AOCS Press.
Kuentz, M. \& Röthlisberger, D. 2003. Rapid assessment of sedimentation stability in dispersions using near infra red transmission measurements during centrifugation and oscillatory rheology. European Journal of Pharmaceutics and Biopharmaceutics 56(3): 355-361.

Loo, C.H., Ismail, R., Basri, M., Lau, H.L.N., Tejo, B.A., Hassan, H.A., Choo, Y.M. \& Kanthimathi, M.S. 2014. Nanostructured lipid carriers (NLC) for efficient delivery of palm phytonutrients. Journal of Oil Palm Research 26(3): 232-239.

Patel, M., Crank, M., Dornburg, V., Hermann, B., Roes, L., Husing, B., Overbeek, L., Terragni, F. \& Recchia, E. 2006. Medium and long-term opportunities and risks of the biotechnological production of bulk chemicals from renewable resources - The potential of white biotechnology. The BREW project. www.bio-economy.net/applications/files/ Brew project report. pdf. Accessed on 11 May 2010.

Peterman, W. 2011. Uses of Glycerine. http://www.livestrong com/article/63424-uses-glycerine/. Accessed on 1 August 2013.

Rieger, M.M. \& Rhein, L.D. 1997. Surfactant Science Series, Volume 68, Surfactants in Cosmetics (2nd ed., Revised and Expanded). New York: Marcel Dekker, Inc.

Sina, J.F., Galer, D.M., Sussman, R.G., Gautheron, P.D., Sargent, E.V., Leong, B., Shah, P.V., Curren, R.D. \& Miller, K. 1995. A collaborative evaluation of seven alternatives to the Draize eye irritation test using pharmaceutical intermediates. Fundamental and Applied Toxicology 26: 20-31.

Yusof, Y.A., Bakar, R.A., Lye, O.T. \& Ahmad, S. 2010. A process for producing etherified compounds from alcohol. MY-142751-A.

Zafarizal Aldrin, A.H., Ismail, R. \& Ahmad, S. 2005. Safety evaluation for dermal and ocular irritation of palm dihydroxystearic acid as a cosmetics ingredient. Journal of Oil Palm Research 17: 160-167.

Yusrabbil Amiyati Yusof* \& Zafarizal Aldrin Azizul Hasan Consumer Product Development Unit Advanced Oleochemical Technology Division

Malaysian Palm Oil Board

6, Persiaran Institusi, Bandar Baru Bangi

43000 Kajang, Selangor Darul Ehsan

Malaysia

Azhar Ariffin

Chemistry Department, Faculty of Science

University of Malaya, Lembah Pantai

50603 Kuala Lumpur, Federal Territory

Malaysia

*Corresponding author; email: amiyati@ mpob.gov.my

Received: 2 August 2017

Accepted: 20 September 2017 